\title{
Agency Costs, Ownership Structure and Corporate Governance Mechanisms: A Case Study in New Zealand Unlisted Small Companies
}

\author{
Nirosha Hewa Wellalage and Stuart Locke \\ University of Waikato, New Zealand
}

\begin{abstract}
This study investigates the linkage between agency costs, ownership structure and corporate governance in small business. Eleven years of data for 100 unlisted small businesses, are collected and 1099 observations are analysed using as dynamic panel GMM estimation. Various diagnostic tests are utilised to check for stationary and convergence of variables. The results indicate that ownership concentration has the most significant governance effect and also has the largest impact on corporate governance. Moreover, this study finds $U$-shape relationship between internal ownership and performance, which under that agency proxy. Agency costs vary with leverage the life of the business and with its size.
\end{abstract}

\section{Keywords}

Corporate Governance, agency problems, ownership structure, debt, small business

\section{Introduction}

This paper investigates the linkage between agency costs, ownership structure and corporate governance in small business. Governance is generally considered be important in contributing to owners' rights and benefits and through strategic policies enhancing performance and creating wealth. However, shareholder value-add has predominantly been investigated for listed public companies, and discussion of governance in the domain of small business has largely been concerned with the lack of professional directors and the lack of division between owners, board and management.

Corporate governance is currently a major issue, attracting considerable attention from policymakers, lawmakers, company executives, shareholders, banks, investors and financial professionals. However, most of this attention has focused on large listed corporations (Gabrielsson and Huse 2004;Hart 1995) and little empirical work relates to how governance impacts agency costs for smaller business.

Small businesses take many forms, include sole proprietorships, family businesses, partnership, private companies, joint ventures, unlisted companies and the terminology may vary from country to country. Most small businesses are owned and controlled by single individuals (founders) or the founder's family. In many cases, owners play a significant direct role in management. The complex interaction between the family and the firm creates several difficult governance issues. The lack of reflexibility among policymakers, lawmakers and other government institutions and the adoption of generic strategies for businesses may be detrimental to small businesses and consequently long-term economic growth. 
Corporate governance contributes to the decision making process, procedures, and attitudes that assist a business in achieving its objectives. As the small business seeks to improve the professionalism and sustainability of its activities, it needs to give greater thought to issues of governance. However, small businesses lack the resources to assist themselves in making important decisions about governance. Also, the legal form of ownership and reality might differ. An example, is showing a husband and wife as shareholders and directors where the reality may be that she is a silent "partner" who is neither actively involved in the day-to-day operation of the business nor its governance.

The establishment of an effective governance framework promotes the small firm's continuity and success beyond the effort of one person, allows for businesses to grow in size and maturity, and succession beyond the working life of the founder. Good governance should improve the decision making and strategic vision of the business, making it easier to monitor and manage the various risks, especially as it grows and matures.

An important issue for small businesses is finance. Smaller firms are often reluctant to try to raise capital from banks and other financial institutions tending to rely on owners' contributing loan funds, which are in essence quasi-equity. Recent research finds debt is one of the most effective mechanisms for improving corporate governance in family firms through mitigating the expropriation of minority shareholders wealth by family founders (Setia-Atmaja, Tanewski and Skully, 2009).

This study extends the current literature on corporate governance practices in several ways. First it addresses issues relating to corporate governance in unlisted firms in different organisational contexts, ownership structure, leverage, the stage within the firm's life cycle, size and industry of the firm. Second it is considers both the principal-agent (PA) and principal-principal (PP) agency costs in these context. Third, the econometric analysis is more robust than prior research due to the use of GMM dynamic panel technique to control the endogeneity effect of insider ownership and reverse causality impact of agency costs. The majority of recent studies ignore the endogeneity effect of insider ownership even though they used a 2SLS regression technique. This paper finds a U-shape relationship between internal ownership and agency costs proxies indicative of managerial entrenchment.

The next section reviews prior research and develops the hypotheses and is followed by data, variables, methodology and procedures used for this empirical study. The results and conclusion then follows.

\section{Literature review}

The efficiency of corporate governance mechanisms associated with publicly listed companies is the subject of extensive ongoing research in the literature (McKnight and Weir 2009; Singh and Davidson 2001; Ward and Filatotchev 2009). However, there is a paucity of prior research addressing the issues as they relate to small and medium enterprises and more specifically the small to micro business sectors.

Limited data availability for research on corporate governance in smaller firms undoubtedly has contributed to the limited literature concerning governance in smaller firms. Prior research to corporate governance in small firms has tended to focus specifically on the role of boards (Daily et al. 2003; Finkelstein and Mooney 2003; Gabrielson 2003; Heuvel et al. 2006; Huse 2000). The board of directors is only one aspect of corporate governance, especially for smaller firms, where most do not have formal boards and when they do, they may contribute very little. There is a need to consider more than just one board structure and function as defining corporate governance in smaller firms. Survey results of Hessels and High (2006) show that for Dutch SMEs with between 1 and 99 employees only 3 percent have boards of directors. Uhlaner et al. (2007) adopt a broader perspective of corporate governance in privately held firms in the Netherlands, considering the roles of owner, financial reporting and auditing, and executive remuneration as other governance mechanisms in small firms. They also consider privately held firms in different life-cycle stages and their respective governance structures and mechanisms. 
A fundamental plank for a corporate governance system is to address the agency issue. As cited by Cheffins and Bank (2009), the foundation of agency theory was established in 1932 when Berle and Means (1932) first discussed the notion of the separation of firm owners (principals) and firm management (agents). As the concentration of ownership becomes more dispersed, the gap tends to widen between the control of the company being with the owners and control being with those appointed to manage the firm. Principal to Principal (PP) agency theory is based upon the conflict between different shareholders (principals) of the firm, more specifically between majority shareholders and minority shareholders. This conflict arises due to the different aims of the owners, which results in a consequential expropriation of profits (Ward and Filatotchev 2009). In small unlisted businesses the owners or founding families tend to hold considerable and undiversified equity positions in their firms. Also, in many cases, owners or members of founding families are directly involved in top management or supervisory board activities. The management-shareholder conflict appears to reduce or disappear in small unlisted businesses.

Randoy and Goel (2003) argue that founding leadership is an alternative corporate governance mechanism that can effectively be used as a monitoring mechanism for small businesses. A study of 68 SMEs in Norway indicates that direct monitoring by owners is a guide to lower agency costs in small businesses. McConaughy et al. (2001) support this perspective, suggesting that founding family control is a key to reduce agency costs and to attain superior firm financial performance.

However, Hessels and High (2006) explain that due to asymmetric information and conflict of owners' interest agency problems are likely in smaller firms. In more recent times, a number of studies show that even though traditional agency costs appear to be reduced in smaller firms, there are other smallfirm-specific agency problems that arise. These agency threats can arise because the interests of the executive may not necessarily coincide with those of the extended family; the lack of separation between ownership and control leads to reduced formal safeguards; family involvement leads to adverse selection of employees; and altruism towards family members can lead to inefficiencies (Anderson and Reeb 2003; Gomez-Mejia et al. 2001; Schulze et al. 2001, 2003; Smith 2008). Further, Uhlaner et al. (2007) examine owner commitment to the firm and other ownership characteristics concerning relational governance of unlisted privately held firms. An investigation of 233 directors of Dutch firms with at least 10 employees, finds support for stewardship theory. In an Australian SME context, Fleming et al. (2004) test the relationship of ownership and agency cost finding a positive relationship between equity agency costs and ownership separation.

However, the existing literature fails to identify an optimal figure for insider ownership. The discussions have issued the impact of an endogeneity effect with ownership structure. Demsetz and Lehn (1985) suggest that ownership structure of the companies is determined by firm size, stock price volatility, industry affiliation etc. According to their suggestions insider ownership may have endogeneity effect. The following hypotheses are postulated in regarding the insider ownership and corporate agency costs proxies in unlisted businesses.

$\mathrm{H}_{1 \mathrm{a}}$ : Having taken account of endogeneity of insider ownership, there will be statistically significant relationship between insider ownership and PA costs in unlisted companies

$\mathrm{H}_{1 b}$ : Having taken account of endogeneity of insider ownership, there will be statistically significant relationship between insider ownership and PP costs in unlisted companies

Highly concentrated insider ownership may expropriate company wealth and give issue to a high freerider problem. Families and individuals are capable of expropriating wealth from the firm through excessive compensation, related-party transactions, or special dividends (Anderson and Reeb 2003). A number of studies find non-linear relationship between internal ownership and agency costs (Morck et al. 1988; Park and Jang 2010; Weir et al. 2002). However, Park and Jang (2010) explain that until 
an optimal breakpoint is reached the convergence of interest with insider ownership increases firm performance and managerial entrenchment will decrease firm performance after the optimal point. This is in line with that, McConnell and Servaes (1990) and Morck et al. (1988) who find an inverse U-shape relationship between insider ownership and firm performance. This is an accord with the existence of managerial entrenchment above a critical level of ownership. The next hypotheses are postulated as entrenchment prediction:

$\mathrm{H}_{2 \mathrm{a}}$ : The insider ownership has U-shape relationship with PA agency costs

$\mathrm{H}_{2 \mathrm{~b}}$ : The insider ownership has U-shape relationship with PP agency costs

Jensen and Meckling (1976) argue that debt is an important influence on agency costs. Firms with higher levels of debt are more closely monitored by debt holders and thus managers have fewer opportunities to pursue non-value maximising activities. Jensen and Meckling (1976) also indicate that debt reduces agency costs by reducing the available free cash flow from which managers can draw benefits. Yuk-Chow (2005) using small business data finds that the overall effect of bank monitoring has a negative affect on small business. He explains that the benefits of bank monitoring may need to be weighed against the associated "hold-up costs" for small businesses. Vos and Forlong (1998) find that debt has a negative agency advantage (defined as reducing agency costs of equity) for small businesses, a significant but minor advantage at the IPO stage, and a significant advantage at the mature listed stage. Furthermore, Harvey et al. (2004) conduct tests to determine whether debt can mitigate the effects of agency problems, focusing on emerging market companies for which pyramid ownership structures create potentially extreme managerial agency costs. The results show that the incremental benefit of debt is concentrated in firms with high expected managerial agency costs. These firms are also most likely to have over-investment problems, resulting from high levels of assets in place and/or limited future growth opportunities. The, next hypotheses are formulated regarding corporate governance, agency costs and firm leverage in unlisted businesses.

$\mathrm{H}_{3 \mathrm{a}}$ : PA agency costs will be lower the higher the level of firm leverage

$\mathrm{H}_{3 \mathrm{a}}$ : PP agency costs will be lower the higher the level of firm leverage

Four variables are included in this study as control variables, namely firm size, firm performance, firm age and industry type. Firm size is considered one of the important factors or variables in organisational studies. Dean et al. (1998) show firm size is related to industry sunk costs, concentration, vertical integration and overall industry profitability. According to official figures (SMEs in New Zealand: Structure and Dynamics 2009) in New Zealand, the percentage of small business start-ups surviving increases with the number of employees. There is a 40 percent survival rate for sole traders, 55 percent for the 1-5 employees group, 62 percent for the 6-9 employees group, increasing to 80 percent of the 50-99 employees group. Guillen (2000) posits that the size of the firm has a positive affect on the quality of corporate governance as larger firms have comprehensive resources to adopt quality governance system vis a versa. However, Woodward and Alchian (1988) use fortune 500 firms and find that firm size is negatively correlated with the agency cost of the firm.

Storey (1994) notes that, younger firms have higher death rates and faster growth rates than mature firms. In New Zealand, figures suggest that 53 percent of small to medium-sized enterprises (SME) fail within the first three years (Mason 2010). As the firm matures, technology adaptation, degree of diversification and expertise in the management team gradually increase (Campa and Kedia 2002). These factors may increase firm financial performance. Conversely, older firms may be less efficient when compared to their younger counterparts due to high costs, dropping profitability, aging assets, slow growth, and decline in R \& D investments. It is still unclear whether maturity helps businesses prosper.

Survival of small business may also depend on the sensitivity of certain industries to change in the microeconomic factors. SMEs in New Zealand: Structure and Dynamics (2009) shows there is a 
noticeable industry effect, on the survival rates in unlisted New Zealand businesses over five years conspicuously lower in mining, education and training, health care and social assistance industries.

\section{Data}

This study uses secondary data for unlisted small businesses regarding ownership structure and financial indicators for the period 1998 to 2008 inclusive, and was made available by the Management Research Centre of the University of Waikato. The random sample is drawn from accounting practices that prepare end of year financial returns for small businesses. This approach avoids the selection bias of using bank related data or figures from those businesses that submit survey responses to government agencies. Eleven years of data for each business are used and, given the high attrition rate for SMEs, the result is an unbalanced panel dataset. Firms included in the study come from a range of industries. A zero equity agency costs benchmark (in terms of expense ratio, assets utilisation ratio and income ratio) is synthesised for sole proprietorship. The final sample comprises 100 firms with 1099 firm-year observations over an eleven years period.

\section{Method}

Panel data analysis is the most efficient statistical method (Madalla. 2001). The panel data set consists of cross sectional and time series data. The panel data structure allows for taking into account the unobservable and consistent heterogeneity, which are specific features of each selected company. The OLS form of panel regression requires that ownership and other control variables are strictly orthogonal to the errors, and that the errors are independently and identically normally distributed with a mean of zero and variance equal to $\sigma^{2}$. The existence of at least one source of endogenity (dynamic endogenity, simultaneity and unobservable heterogeneity) in the data generating process will cause the estimates to be biased and inefficient. The direction of causality of ownership and agency costs can be determined by characteristics of the firm or its agency costs.

The early ownership and agency costs literature assumed ownership is an exogenous factor to firm agency costs (Fleming et al. 2004; Singh and Davidson 2001). However, McKnight and Weir (2009) treated the endogenous problem in ownership and agency perspectives using instrumental variables.

In the presence of endogenity, the panel OLS estimation approaches will produce biased parameter estimates. To obtain robust estimates, a GMM panel estimator is used to estimate the relationship between ownership and agency costs. Using the GMM method builds instrumental variables for potentially endogenous variables.

In particular, it is important to determine whether there is an endogenity effect present in the ownership variable. Durbin-Wu-Hausman (DWH) test is applied to check the endogenity of agency proxies and other variables. The results for the DWH confirm endogeneity effect in insider ownership. This finding confirms that OLS coefficient-estimates are unreliable and biased. The result of the DWH test for endogenity points to the need to use a dynamic panel GMM estimator. The GMM panel estimator was introduced by Holtz-Eakin et al. (1988) and Arellano and Bond (1991) and further developed Arellano and Bover (1995) and Blundell and Bond (1998).

The basic GMM estimation consists of two steps. First, a dynamic model with first-differenced form. This first differencing eliminates potential bias that can arise from unobservable heterogeneity.

Arellano and Bover (1995) and Blundell and Bond (1998) improve the GMM estimator by including equations in levels also known as stacks, in the estimation procedure. This uses lagged differences as instruments for the equation in levels and these in turn to become instruments for the first-difference equations. This GMM estimation enables efficient estimators to be obtained while maintaining all the essential elements of controlling for unobserved heterogeneity and simultaneous and dynamic endogenity. 
Further, Arellano-Bond (AR1) and (AR2) indicates no auto correlation in the dynamic GMM estimation and Hansen/Sargan J-statistics, indicates that the null hypothesis that the moment conditions are correctly specified cannot be rejected at all significant level for dynamic GMM model.

\section{PA and PP regressions}

Following Ang et al., (2000) the first proxy for agency costs is the ratio of operating expenses to annual sales as a measure of operating expenses. Second PA proxy is the ratio of annual sales to total assets which is a measure of assets utilisation. Faccio et al. (2000) propose measuring PP costs using dividend payout. In the case of small businesses, dividends may not necessarily be appropriate, e.g. for a non-company structured firm, so an alternative profit distribution metric is necessary. The independent variables, which are either continuous or binary, fall into one of three categories relating to corporate structure, external monitoring and control variables. Corporate structure variables are: working owner $0 \%$ group (Nil), working owner $0 \%-25 \%$ (Low), working owner $25 \%-50 \%$ (Medium), working owner $50 \%-75 \%$ (High) and, working owner $>=$ to $75 \%$ (Highest). As indicated by Ang et al (2000), 100\% ownership forms used as no-agency costs base case firms for comparison. Further variables are: leverage (leverage), natural $\log$ of number of staff (lnstaff), natural log of firm age (lnage and includes 4 industry dummies representing primary (Industry1), energy (Industry2), goods (Industry3) and services industries (Industry4). Appendix provides a summary of the variables along with definitions.

\section{Results}

Table 1 reports the descriptive statistics for the data. The approximation of mean value for insider ownership is 42.11 , the highest percentage of insider ownership is 100 percent in unlisted small businesses and the lowest insider ownership representation is 0 percent. This highlights the existence of insider ownership in unlisted business in New Zealand. Number of staff varies in between 0 to 196 with mean value of 8 staff members. The sample consists with young firms with an average 8.1 years and age ranging between 1 year to 25 year.

\section{PA agency costs}

The regression analysis is undertaken in five steps using the panel data. These five steps involve regressing the ratio of operating expenses to annual sales on each of the variables while controlling for managerial ownership variables (nil, low, medium and high and highest). Table 2 presents the results for the operating expenses to sales measure of agency costs. Columns 2-6 of Table 2 present OLS results and columns 7-11 present dynamic panel GMM results. The second group of regression analysis follows a similar five stage process using the ratio of sales to assets as the dependent variable. Table 3 presents the results for the sales to assets measure of agency costs and these are discussed below under findings. An examination of the results in Table 2 and Table 3 reveals that endogenity is a significant concern of ownership.

The findings suggests that corporate governance in smaller firms relates to governance in different organisational contexts (ownership context of the firm, the stage within the firm's life cycle, industrial sector and size of the firm) which is consistent with PA and PP agency theory. The sign on the coefficients is important in terms of whether the explanatory variables make a positive or negative contribution to PA cost. The finding in terms of expense ratio and working ownership percentage, calculated as the proportion of working owners to total fulltime staff are shown in Table 4. Firms with the lowest working ownership (0\%) have the highest expense ratio. However, firms with the highest working ownership ( $>=75 \%$ ) have again high expense ratio, suggesting private expenses are probably channelled through the business.

The relationship between asset utilisation and working ownership percentage are shown in Table 3 . It is apparent that agency cost is highest when there is $>=75$ percent working ownership and lowest working ownership ( 0 percent) proportions. These figures are consistent with the view that high levels of managerial ownership in small businesses exploit the business. The majority shareholders/owners, or family members as managers, use their position to deprive the non-family 
members or family not in the inner circle or minority shareholders of influence over majority decisions and expropriate business assets for their personal gain. Results show U-shape relationship with working ownership and equity agency costs. This is in line with McConnell and Servaes (1990) and Schooley and Barney (1994) agency costs decline with increases in managerial ownership to a certain point, however, after that entrenchment occurs, agency costs grow with increased managerial ownership.

The expense ratio is significantly positively related to a firm's debt-to-assets ratio. In part, the accounting conventions result in measurement problems for debts and assets in small businesses. The adoption of international financial reporting standards (IFRS) in most countries, except the USA, will assist in ensuring debt and asset measures are market based. It is noted that IFRS will be very watered down when it comes to small business but there may still be an improvement in information transparency where countries mandate a standard. The difficulty caused by historical cost assets having low written down values and debt being at market value distorts the numbers and introduces an ageing bias. Asymmetric information is often stated as the cause of understand the relationship between bank and small business. This is confirmed by Han et al. (2009) who investigated US small business and argue that "high type" entrepreneurs, who transfer secure and transparent information, enjoy preferential advantages with their bank obtaining lower interest rates than entrepreneurs who transfer weak information to the bank. The evidence suggest that, in contrast with larger listed firms, debt is not an appropriate external corporate governance mechanism for smaller unlisted businesses in terms of an expense ratio.

The sign-on debt in the expense ratio regression indicates an increase in debt is associated with an increase in PA agency costs. However, the sign-on debt in the assets utilisation regression indicates an increase debt is associated with a decrease PA costs. The extent to which debt holders will monitor the performance of small business remains an open question. Quasi-equity, i.e., loans from the owner(s), can represent a significant portion of debt (Cosh and Hughes, 1994). There is evidence to suggest that information asymmetry often leads to frustration with small business (Ang 1992; Gregory et al. 2005). Similarly, Garc'ia-Teruel and Mart'inez-Solano (2008), note that SMEs suffer more information asymmetry than their larger counter parts giving rise to more agency conflicts from debts than larger companies in Spain.

Results indicate that log of staff number; proxy for firm size is significantly correlated with the expense ratio (assets utilisation ratio). This finding is consistent with Fleming et al. (2004) in an Australian SME context. Further findings suggest corporate governance in smaller businesses relates to the industrial sector within which a firm finds itself. Consistent with Huse (2007) and Zahra and Pearce (1989), there are variations across industrial sectors with respect to technologies, ownership patterns, resources configurations and environment. These factors have different influences on the corporate governance in small business.

PA and the maturity of the firm is statistically significant in higher insider ownership groups, indicating that assets utilisation decreases with the age of the firm. Older firms are seen as less efficient, because company aging increases organisational rigidness and rent-seeking behaviour. Consistently, Table 2 shows positive relationship in between expense ratio and maturity of the firm with lowest and highest insider ownership groups, indicating agency costs is increase with the age of the firm. This suggests that the governance mechanism of small businesses is related to the life cycle of the firm.

\section{PP agency costs}

Proxy for the proposed dividend payout metric of Faccio et al. (2000) is necessary as many small businesses do not use dividends as a method of distributing profit. The PP proxy, net income/number of working owners divided by total sales, is regressed against ownership structure, industry, and control variables. The regression analysis follows a five step process similar to that used in the PA analysis above. Table 4 presents the results for the profit per owner ratio measure of PP costs, and 
these are discussed below under findings. Table 4 columns 2-6 represent panel OLS results and column 7-11 represent dynamic panel GMM estimator results.

Table 1. Descriptive statistics

\begin{tabular}{|c|l|l|l|l|l|}
\hline Variable & Obs & Mean & Stan. Dev & Min & Max \\
\hline Inopexsal & 1100 & -2.103062 & .7991096 & -4.494563 & .2651079 \\
\hline Insalass & 1100 & .8948383 & .9497011 & -2.802817 & 12.66509 \\
\hline divsal & 1100 & .134667 & .1889433 & -.3948126 & 3.232396 \\
\hline ownership & 1100 & 42.117 & 33.10633 & 0 & 1 \\
\hline low1 & 1100 & .0363636 & .1872784 & 0 & 1 \\
\hline low2 & 1100 & .3345455 & .4720459 & 0 & 1 \\
\hline low3 & 1100 & .4154545 & .4930244 & 0 & 1 \\
\hline low4 & 1100 & .04 & .1960483 & 0 & 1 \\
\hline low5 & 1100 & .1736364 & .3789688 & 0 & 1 \\
\hline Staff & 1100 & 8.214991 & 17.2089 & 0 & 3.218876 \\
\hline lnstaff & 909 & 1.45306 & 1.293682 & -2.995732 & 5.278115 \\
\hline leverage & 1100 & .8838016 & 1.608701 & 0 & 36.04424 \\
\hline Age & 1099 & 8.105551 & 3.975306 & 1 & 25 \\
\hline lnage & 1099 & 1.935046 & .624655 & 0 & \\
\hline
\end{tabular}

PP agency cost is found to be correlated with variables noted in previous studies. In Table 4 the figures indicate that the working ownership percentage is inversely correlated with the PP agency cost proxy. Firms with the lowest working ownership (0\%) and highest working ownership percentage $(>=75 \%)$ have the highest PP agency costs, higher managerial ownership is positively correlated with PP agency costs consistent with higher managerial ownership using its position to deny the minority shareholders of influence over the distribution of business earnings. Similar to PA the U-shape relationship exists between PP agency costs and working ownership percentage.

The size of the business is negatively correlated with PP, as reflected in Table 4, indicating that as firms grow there is a reduction in the potential for PP costs. Next it is noted that industry factors play an important role, with some industries being more prone to PP costs than others, which is similar to the observation of (Chrisman et al. 2003). As profitability declines and the surpluses diminish, the opportunity to divert relatively more resources to the major owners decreases. The maturity of the business is negatively correlated with PP cost, suggesting that longer-life businesses are not only profitable in a sustainability sense but exploitation by senior owner(s) is not so apparent.

PP cost has a significant negative correlation with leverage, which is consistent with Setia-Atmaja et al. (2009) who propose that with more debt there is a decrease PP agency cost, noting the 
measurement issues concerning both debt and equity in small businesses. As the proportion of debt in the capital structure increases so too does the interest expense with associated demand on cash flow, and it appears this situation curtails the likelihood of a major owner diverting additional resources in his or her own direction. Setia-Atmaja et al. (2009), suggest that the governance role of debt in family firms/SMEs is determined by the capital market effectiveness of particular country. They further point out that high transparency of corporate accounts and where highly developed shareholder and creditor rights exist this leads to higher debt levels in family firms mitigating PP problem. 


\begin{tabular}{|c|c|c|c|c|c|c|c|c|c|c|c|c|c|c|}
\hline & 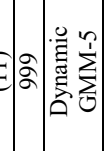 & 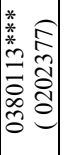 & & & & & 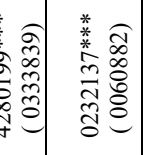 & 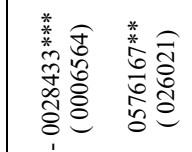 & 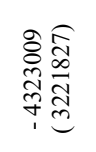 & 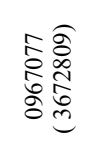 & 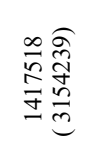 & 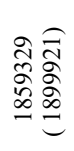 & & 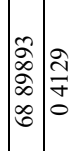 \\
\hline & 结 & $\mid$ & & & & 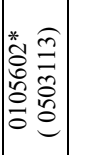 & 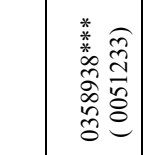 & 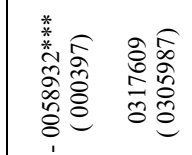 & 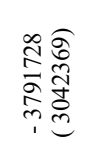 & 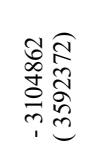 & 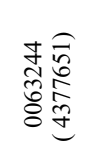 & 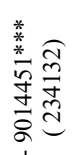 & & 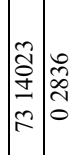 \\
\hline & సే & $\mid$ & & & 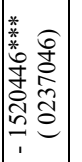 & & 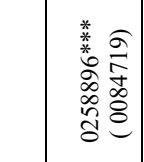 & 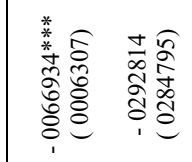 & 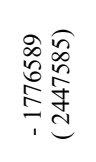 & 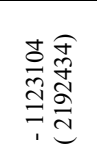 & 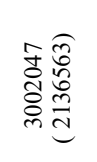 & 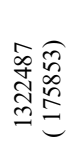 & & 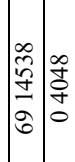 \\
\hline & 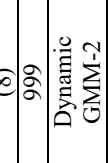 & $\left|\begin{array}{ll}7 & 0 \\
0 & 0 \\
0 & 0 \\
0 & 0 \\
0 & 0 \\
1 & 0\end{array}\right|$ & & 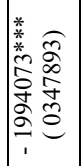 & & & 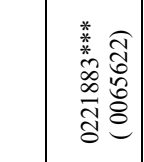 & 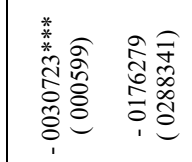 & 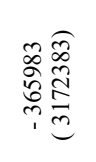 & 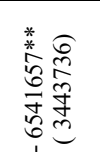 & 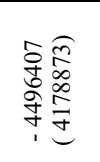 & 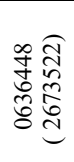 & & 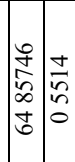 \\
\hline & : & $\mid$ & 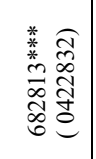 & & & & 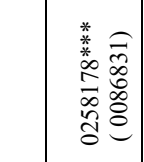 & 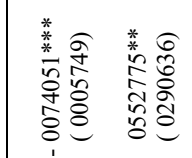 & 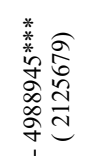 & 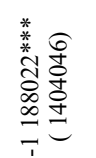 & 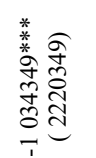 & 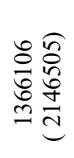 & & 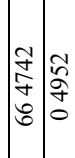 \\
\hline & & & & & & & 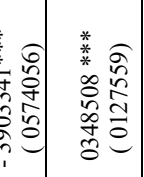 & 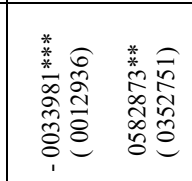 & 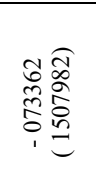 & 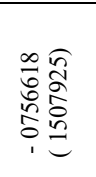 & 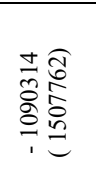 & 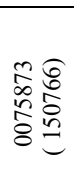 & & \\
\hline & & & & & & 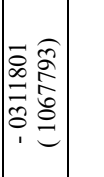 & 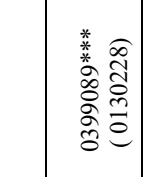 & 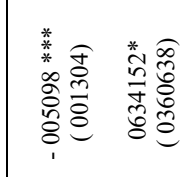 & 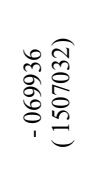 & 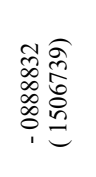 & 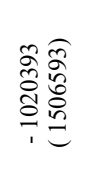 & 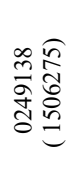 & & \\
\hline & & & & & 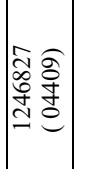 & & 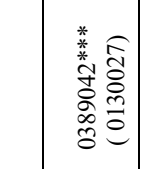 & 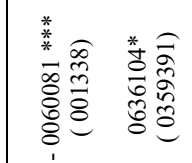 & 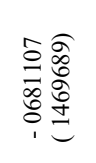 & 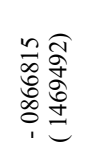 & 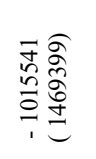 & 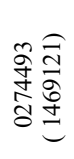 & & \\
\hline & & & & 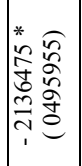 & & & 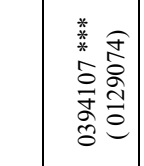 & 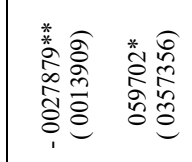 & 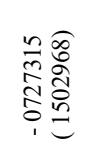 & 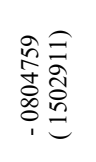 & 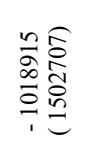 & 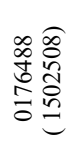 & & \\
\hline & 3 & & 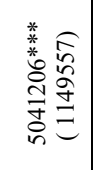 & & & & 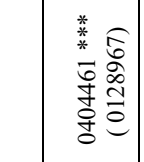 & 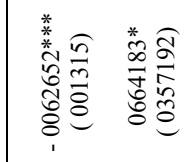 & 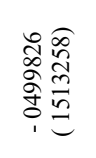 & 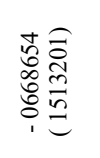 & 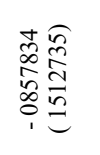 & 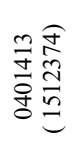 & & \\
\hline & 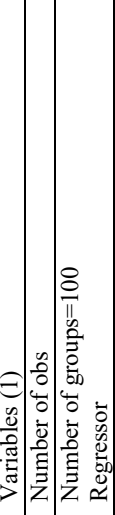 & 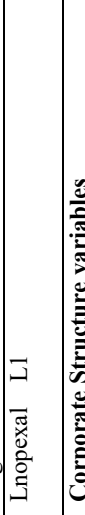 & 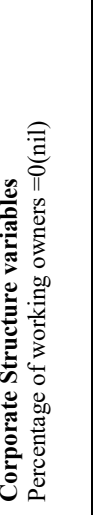 & 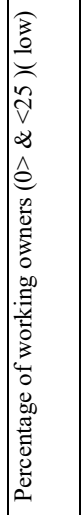 & 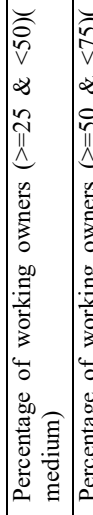 & 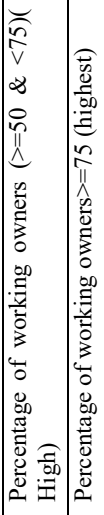 & 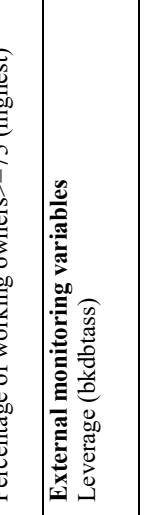 & 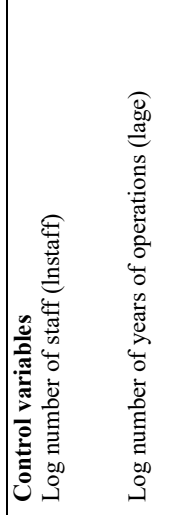 & 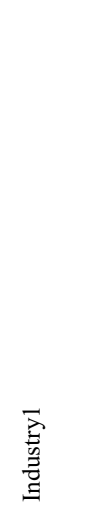 & 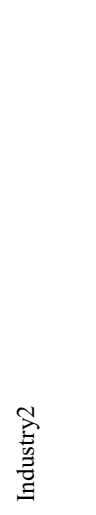 & 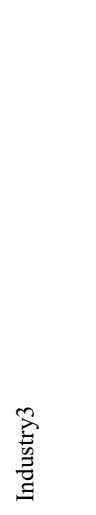 & 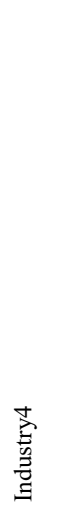 & & 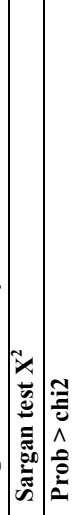 \\
\hline
\end{tabular}




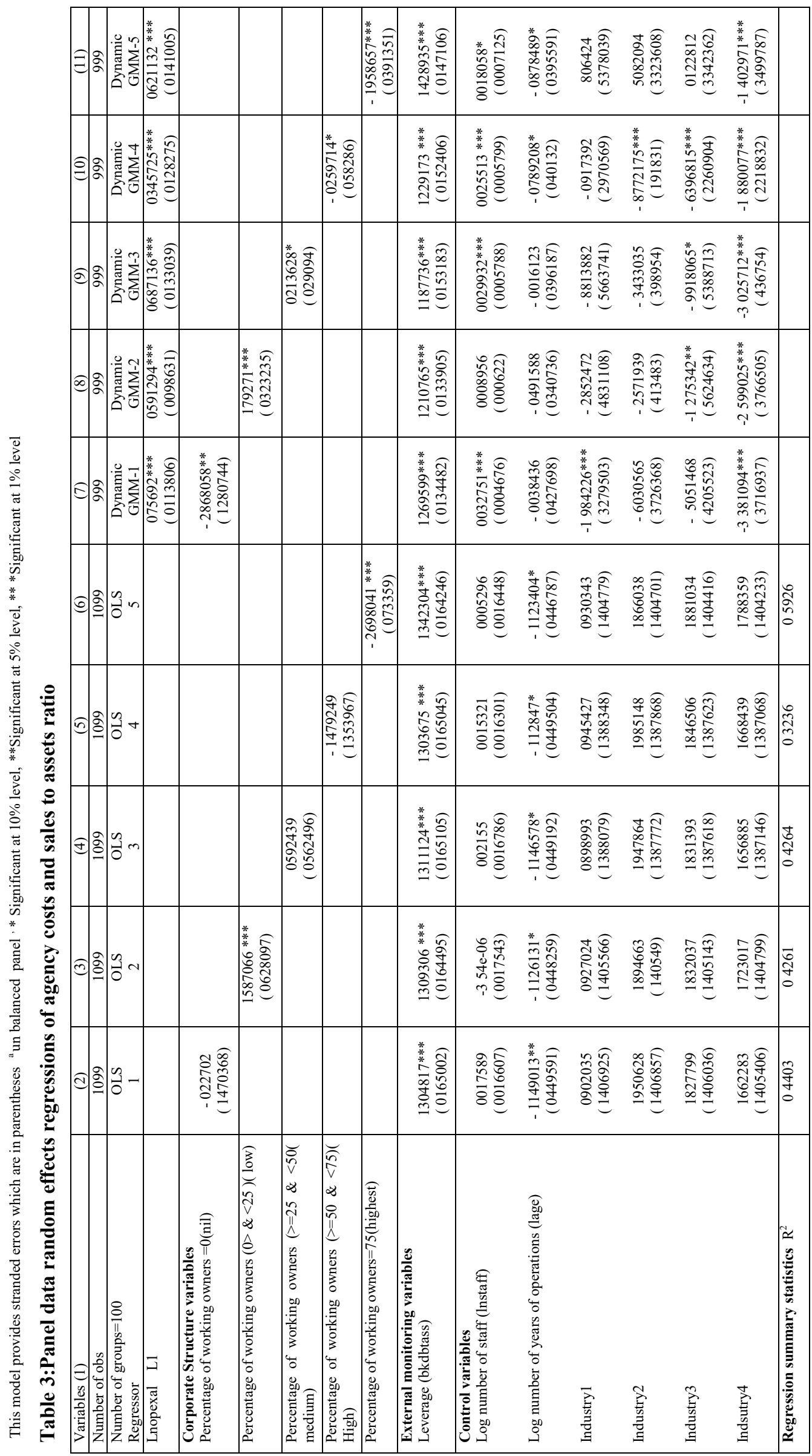




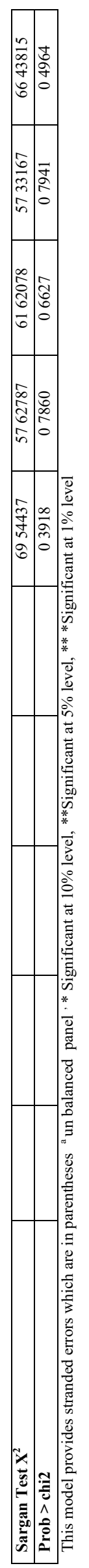

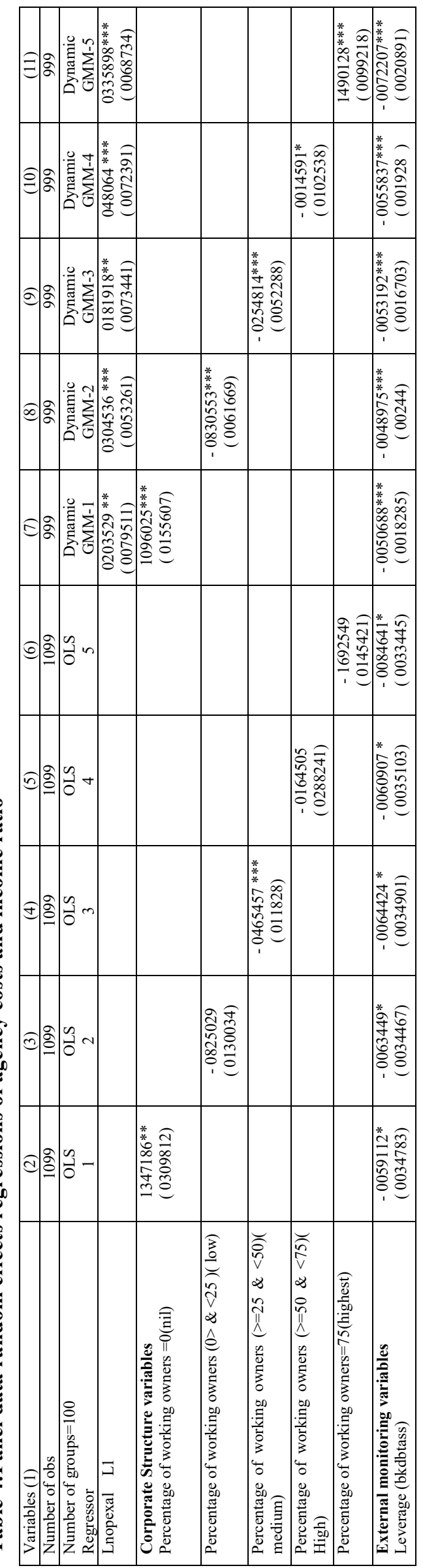




\begin{tabular}{|c|c|c|c|c|c|c|c|}
\hline 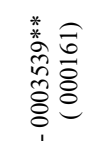 & 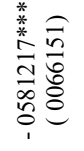 & 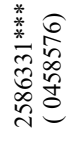 & 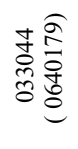 & 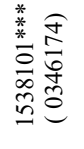 & 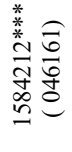 & & \begin{tabular}{l}
$\infty$ \\
\hdashline \\
\hdashline \\
0
\end{tabular} \\
\hline 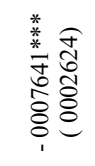 & 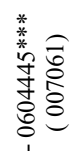 & 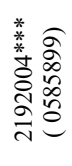 & 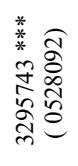 & 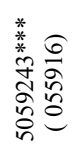 & 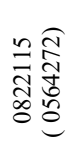 & $\begin{array}{l}\infty \\
\tilde{N} \\
\tilde{o} \\
\tilde{\sigma}\end{array}$ & $\begin{array}{l}\overrightarrow{\hat{f}} \\
\mathbf{b} \\
0\end{array}$ \\
\hline 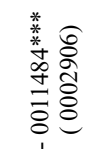 & 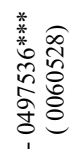 & 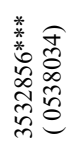 & 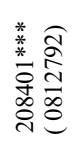 & 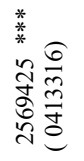 & 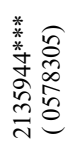 & 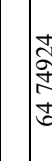 & $\begin{array}{l} \\
\tilde{n} \\
n \\
0 \\
0\end{array}$ \\
\hline 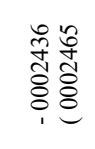 & 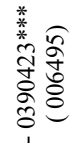 & 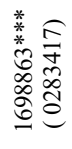 & 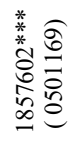 & 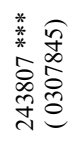 & 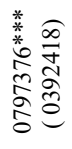 & 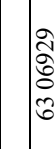 & $\begin{array}{l}n \\
0 \\
0 \\
0 \\
0\end{array}$ \\
\hline 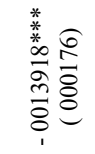 & 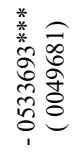 & 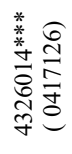 & 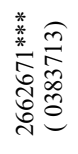 & 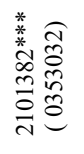 & 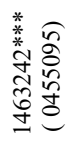 & 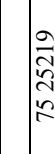 & $\begin{array}{l} \\
\vec{\partial} \\
\vec{Z} \\
0\end{array}$ \\
\hline 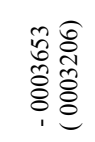 & 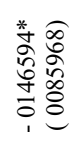 & 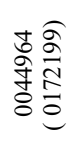 & 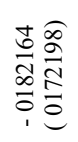 & 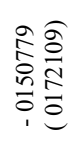 & 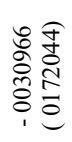 & ڤ్ర & \\
\hline 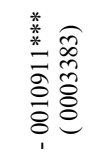 & 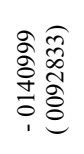 & 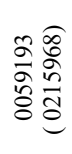 & 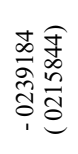 & 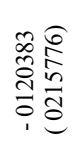 & 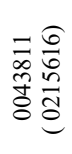 & 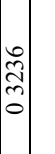 & \\
\hline 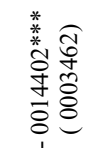 & 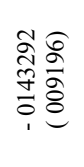 & 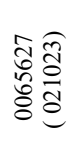 & 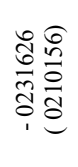 & 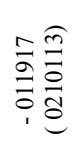 & 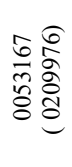 & 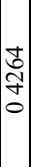 & \\
\hline 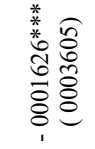 & 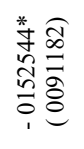 & 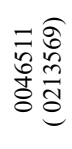 & 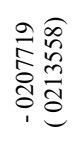 & 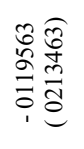 & 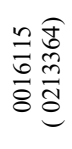 & 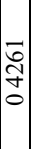 & \\
\hline 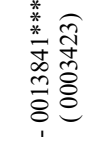 & 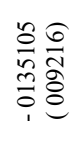 & 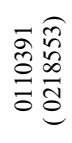 & $\begin{array}{l}\infty \\
0 \\
0 \\
0 \\
\infty \\
0 \\
0 \\
0 \\
1\end{array}$ & 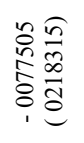 & 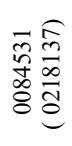 & 官 & \\
\hline 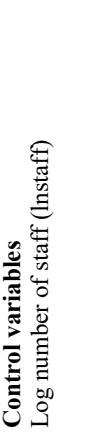 & 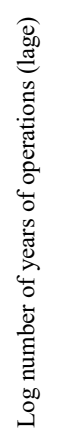 & $\begin{array}{l}\bar{\lambda} \\
\text { 尊 } \\
\bar{z}\end{array}$ & 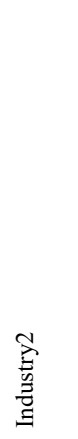 & 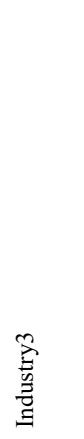 & 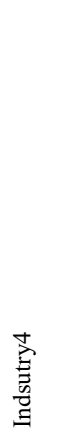 & 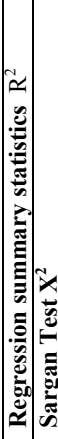 & 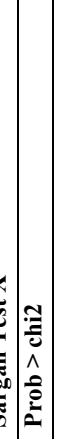 \\
\hline
\end{tabular}




\section{Implications}

The research indicates that PA and PP agency costs are present in small business and in many instances these findings are consistent with prior research for listed businesses. Managerial ownership seems to be a primary determinant of corporate governance, though majority owners use their position to deprive the minority owners of influence over decisions and/or distribution of business earnings. As the number of owners change, the potential for one managing owner, or family group to expropriate the profit of other owners, becomes more pronounced. Minority interests could be protected by rules that restrict the powers of majority owners. Effective lock-in rules and squeeze-out regulations could important for promote both share transfers and investment in small businesses. PP cost has received no prior consideration in the small business context and, based on the results, it is of considerable importance.

The well-meaning parents who encourage second generation children to participate and then run the business are subject to both PA and PP cost burdens. The requirement for greater disclosure of financial reporting by all businesses, reducing opacity, could potentially reduce this distortion concerning the effective distribution of scarce capital resources. The analysis indicates there is considerable variability in the burden of agency cost. This raises the potential for regulatory and policy reforms that may enhance the productivity and growth in the sector.

The distortion between equity return and debt return arises due to a preference for quasi-equity (loans to the business by the owners), impacting the productive base and affecting the pricing of risk. The common requirement for personal guarantees from the owners to support business loans similarly distorts operational efficiency. As personal risk is increased through granting guarantees, in the absence of a gambling mentality, overall risk taking is reduced and there will be a propensity to ignore potential favourable projects. This adverse selection issue will lower growth and when consider in aggregate lower national living standard increases. The result also tends to be an unnecessary overhead loading and higher bankruptcy costs, which in turn are impounded into the cost of capital. The personal commitments, in terms of guarantees, can lead to the leverage levels of small businesses being misinterpreted where it would be more accurate to include owners' personal loans as equity in the balance sheet. The role leverage plays in shaping corporate governance in small business, is important.

A mis-pricing of risk can potentially distort the market. Given the high bankruptcy cost for small business, around 45 percent of net assets, and the low survival rates, it is rational for lenders to apply high hurdles for loan applicants (SMEs in New Zealand: Structure and Dynamics 2009). Businesses will rationally respond by being less than candid about their financial affairs. This climate of moral hazard will be eased the presence of independent directors. The PP problem increases in the climate of close control of information and one owner being the primary manager/owner. These owners are relatively more aware of the risks inherent in the businesses and they may make decisions subject to adverse selection pressures and expropriate profit to give a fairer return to them, given the risk level of the business as they know it.

The analysis undertaken clearly establishes the existence of PA and PP agency cost. The potential for improvement in such contexts appears limited. Furthermore, the regulatory environment, tax anomalies and the cost of information do not encourage an evolvement toward better governance in smaller businesses. There is a need to develop a corporate governance code for smaller firms that is flexible enough to take account of the different types of governance needs of firms at different stages in their life cycle and the nature of the business.

\section{Limitations}

Notwithstanding the findings, the current study does have limitations, which point to potentially fruitful further research opportunities. First, the current study used one aspect of ownership structure (insider ownership). Further studies could consider other aspects of ownership structure and corporate governance variables, such as ownership concentration, ownership type etc. Second the findings are 
based on research in a single country and may not be generalisable. Further studies in both mature and emerging markets will be helpful in terms of international comparability.

\section{APPENDIX}

APPENDIX: Variable definition

\begin{tabular}{l} 
Variable name \\
\hline Agency Costs \\
Operating expenses to sales (Opexsal)
\end{tabular}

Definition

Operating expenses to sales (Opexsal)

This ratio is calculated as operating expenses divided by annual sales. Operating expenses exclude the labour related expenses such as corporate wages, salaries and so on, and interest expense, rent, leasing and hiring expenses, purchases, depreciation and bad debts written off (\%)

Log of Opexsal (lnopexsal)

Sales to assets ratio (Salass)

Log of salass (lnsalass)

Income ratio (Incratio)

\section{Ownership percentage}

Nil

Low

Medium

High

Highest

\section{External monitoring}

Leverage (bkdbtass)

\section{Control variables}

lnstaff

lnage

Industry 1

Industry 2

Industry 3

Industry 4

\section{Natural log of Opexsal}

This ratio is calculated as total sales divided by total assets.

Natural log of Salass

This ratio is calculated as net income/number of working owners divided by total sales

This ratio is calculated as number of working owners divided by total staff plus number of working owners

Percentage of working owners $=0$

Percentage of working owners $>0$ and $<25$

Percentage of working owners $\geq 25$ and $<50$

Percentage of working owners $\geq 50$ and $<75$

Percentage of working owners $\geq 75$

This ratio is calculated as total debt divided by total assets

Logarithm of number of staff

Logarithm of number of years operating in the industry

Dummy variable 1 , if the industry is equal to primary

Dummy variable 2, if the industry is equal to energy

Dummy variable 3, if the industry is equal to good

Dummy variable 4 , if the industry is equal to services 


\section{References}

Anderson, R C and D M Reeb. 2003. "Founding family ownership and the agency cost of debt 68." Journal of Financial Economics 68:263-286.

Ang, J. 1992. "On the Theory of Finance for Privately Held Firms." Journal of Small Business Finance 1(3):185-203.

Ang, J S, R A Cole and J W Lin. 2000. "Agency Costs and Ownership Structure." The Journal of Finance LV(1):81-106

Arellano, M and Bond. 1991. "Some Tests of Specification for Panel Data: Monte Carlo Evidence and an Application to Employment Equations." Journal Review of Economic Studies 58(2):277-297.

Arellano, Manuel and Olympia Bover. 1995. "Another look at the instrumental variable estimation of error-components models." Journal of Econometrics 68(1):29-51

Blundell, R and S Bond. 1998. "Initial conditions and moment restrictions in dynamic panel data models." Journal of Econometrics 87(1):115-143.

Campa, Jose Manuel and Simi Kedia. 2002. "Explaining the diversification discount." Journal of Finance 57:1731-1762.

Cheffins, B R and S Bank. 2009. "Is Berle and Means really a myth?" Business History Review 83(Autumn):443-477.

Chrisman, J J, J H Chua and S A Zahra. 2003. "Creating wealth in family firms through managing resources: Comments and extensions." Entrepreneurship Theory \& Practice 27(4):359-365.

Cosh, A D and A Hughes. 1994. Size, financial structure and profitability: UK companies in the 1980s Routledge, London.

Daily, C M, D R Dalton and A A Cannella. 2003. "Corporate Governance: Decades of Dialogue and Data." Academy of Management Review 28:341-354.

Dean, T J, R L Brown and C E Bamford. 1998. "Differences in large and small responses to environmental context: Strategic implications from a comparative analysis of business formations." Strategic Management Journal 19:265-273.

Faccio, M, L.H.P.Lang and L. Young. 2000. "Dividends and Expropriation " European Financial Management Journal.

Finkelstein, S and A. C. Mooney. 2003. "Not the Usual Suspects: How to Use Board Process to Make Boards Better." Academy of Management Executive 17(2):101-113.

Fleming, G, R.Heaney and R. McCosker. 2004. "Agency Costs and ownership structure in Australia " Pacific-Basin Finance Journal 13:29-52.

Gabrielson, J. 2003. "Boards and Governance in SMEs: An Inquiry into Boards' Contribution to Firm Perfromance." Halmstad:SIRE.

Gabrielsson, J and M Huse. 2004. "Context, Behavior, and Evolution: Challenge in Research on Boards and Governance." International Studies of Management and Organisations 34(2):1136.

Garc'1a-Teruel, Pedro J. and Pedro Mart'1nez-Solano. 2008. "On the Determinants of SME Cash Holdings: Evidence from Spain." Journal of Business Finance \& Accounting 35(1):127-149.

Gomez-Mejia, L, M Nuñez-Nickel and I Gutierrez. 2001. "The role of family ties in agency contracts " Journal of Small Business and Enterprise Development 7(3):255-260.

Gregory, B, M Rutherford, S Oswald and L Gardiner. 2005. "An empirical investigation of the growth cycle theory of small firm financing." Journal of Small Business Management 43(4):382-392.

Guillen, M F. 2000. "Business Groups in Emerging Economies: A Resource Based View." Academy of Management Journal 43(3):362-380.

Han, Liang, Stuart Fraser and David J. Storey. 2009. "The Role of Collateral in Entrepreneurial Finance." Journal of Banking \& Finance 36(3):424-455.

Hart, O. 1995. "Corporate Governance: Some Theory and Implications." Economic Journal 105(430):678-689.

Harvey, Campbell R., Karl V. Lins and Andrew H. Roper. 2004. "The effect of capital structure when expected agency costs are extreme." Journal of Financial Economics 74:3-30. 
Hessels, S J A and E H High. 2006. "Small Business Governance: An exploration of the meaning and practice of corporate governance in SMEs." Zoetermeer.

Heuvel, Jeroen Van den, Anita Van Gils and Wim Voordeckers. 2006. "Board Roles in Small and Medium-Sized Family Businesses: Performance and Importance " Corporate Governance: An International Review 14(5):467-485.

Holtz-Eakin, D, W Newey and H S Rosen. 1988. "Estimating Vector Auto regressions with Panel Data." Econometrica 56(6):1371-1395.

Huse, M. 2000. "Boards of Directors in SMEs: A Review and Research Agenda." Entrepreneurship and Regional Development 12(4):41-50.

Jensen, M and W Meckling. 1976. "Theory of the Firm: Managerial Behavior, Agency Costs and Ownership Structure." Journal of Financial Economics 3(4):305-360.

Madalla., G S. 2001. Introduction to Econometrics. New York: Wiley.

Mason, Moya K. 2010. "Research on Small Businesses."

McConaughy, D, C Matthews and A Fialco. 2001. "Founding Family Controlled Firms: Performance, Risk and Value " Journal of Small Business Management 39:31-49.

McConnell, J J and H Servaes. 1990. "Additional evidence on equity ownership and corporate value." Journal of Financial Economics 27:595-612.

McKnight, Phillip J. and Charlie Weir. 2009. "Agency costs, corporate governance mechanisms and ownership structure in large UK publicly quoted companies: A panel data analysis." The Quarterly Review of Economics and Finance 49:139-158.

Morck, R, A Schleifer and R Vishny. 1988. "Management Ownership and Market Valuation: An Empirical Analysis,." Journal of Financial Economics 20:293-315.

New Zealand Government, Ministry of Economic Development .2009. "SMEs in New Zealand: Structure and Dynamics 2009." ed. Ministry of Economic Development

Park, K and S S Jang. 2010. "Insider ownership and firm performance: An examination of restaurant firms." International Journal of Hospitality Management 29(3): 448-458.

Randoy, Trond and Snajay Goel. 2003. "Ownership structure, founder leadership, and performance in Norwegian SMEs: Implications for financing entrepreneurial opportunities." Journal of Business Venturing 18:619-637.

Schooley, D and L D Barney. 1994. "Using dividend policy and managerial ownership to reduce agency costs." Journal of Financial Research 17:363-373.

Schulze, W.S, M H Lubatkin and R. N Dino. 2001. "Altruism, Agency and the Competitiveness of Family Firms." Managerial and Decision Economics 23(4/5):247-259.

Schulze, W.S, M H Lubatkin and R. N Dino. 2003. "Toward a Theory of Agency and Altruism in family Firms." Journal of Business Venturing 18(4):473-490.

Setia-Atmaja, L, G A Tanewski and M Skully. 2009. "The role of Dividends, Debt and Board Structure in the Governance of Family Controlled Firm." Journal of Banking \& Finance 36(7):863-898.

Singh, M and W N Davidson. 2001. "Agency costs, ownership structure and corporate governance mechanisms." Journal of Banking and Finance 18(4):473-490.

Smith, Max. 2008. "Differences between family and non-fmaily SMEs: A comparative study of Australia and Belgium." Journal of Management and Organisation 14:40-58.

Storey, D. 1994. Understanding the Small Business Sector. London: Routledge.

Uhlaner, Lorraine, Mike Wright and Morten Huse. 2007. "Private Firms and Corporate Governance: An Integrated Economic and Management Perspective." Journal of Small Business Economics 29:225-241.

Vos, Ed and C Forlong. 1998. "The Agency Advantage of Debt Over the Lifecycle of the Firm." Journal of Entrepreneurial and Small Business Finance 5(3):193-211.

Ward, D and I Filatotchev. 2009. Principal- principal agency relationships and the role of external governance. London: John Wiley and Sons Ltd.

Weir, C, D Laing and P H McKnight. 2002. "Internal and External Governance Mechanisms: Their Impact on the Performance of the Large UK Public Companies." Journal of Business Finance \& Accounting 29(5):579-611. 
Woodward, S and A A Alchian. 1988. "The Firm is Dead: Long Live the Firm A Review of Oliver E.Williamson's The Economic Institutions of Capitalism." Journal of Economic Literature 26(1).

Yuk-Chow, Jacky. 2005. "Agency Costs and Ownership Structure: Evidence from the Small Business Finance Survey Data Base." In Small Business Research Summary Advocacy: The Voice of Small Business in Government. Laredo: Texas A\&M International University.

Zahra, S A and J. A. Pearce. 1989. "Boards of Directors and Corporate Financial Performance: A Review and Integrative Model." Journal of Management 15(2):291-334. 